\title{
Molecular characterization of barley yellow dwarf virus in Tunisia
}

\author{
M. BOUALLEGUE ${ }^{1}$, M. MEZGHANI-KHEMAKHEM ${ }^{1}$, D.BOUKTILA ${ }^{1,2}$, H. MAKNI $^{1,3}$, M. MAKNI $^{1 *}$

\begin{abstract}
${ }^{1}$ Université de Tunis El-Manar, Faculté des Sciences de Tunis, UR11ES10 GIRC, 2092 El Manar, Tunisia; ${ }^{2}$ Université de Jendouba, Institut Supérieur de Biotechnologie de Béja, 9000 Béja, Tunisia; ${ }^{3}$ Université de Tunis, Institut Supérieur de l’Animation pour la Jeunesse et la Culture, Bir-El-Bey, Tunisia
\end{abstract}

Received December 16, 2013 ; accepted July 28, 2014

\begin{abstract}
Summary. - Barley yellow dwarf disease is a worldwide ubiquitous virus disease of cereal crops. In order to characterize the B/CYDV isolates occurring in Tunisia, 240 barley leaves were randomly sampled from 6 fields following a North-South trend and analyzed by serological and molecular tests. DAS-ELISA results showed 40 positive samples with a prevalence of barley yellow dwarf virus (BYDV)-PAV (77.5\%), followed by cereal yellow dwarf virus (CYDV)-RPV (25\%) and BYDV-MAV (15\%). Studies of the geographic distribution showed a high incidence of $\mathrm{B} / \mathrm{CYDV}$ in the Tunisian Southern provinces. RT-PCR assays were performed to amplify the viral coat protein gene (CP) and sequence analyses revealed six BYDV-PAV haplotypes named PAV-TN1 to PAVTN6. Phylogenetic analysis showed that the six Tunisian haplotypes were close to BYDV-PAV-II subspecies and had a strong similarity with Moroccan, Czech, French and German haplotypes. Although PAV-TN2 and PAV-TN5 showed up to $10 \%$ divergence from BYDV-PAV-II at the amino acid level, it seems to belong to the same subspecies but in a separated cluster. Our results will be important in developing appropriate control measures against BYDV disease in Tunisia.
\end{abstract}

Keywords: barley yellow dwarf virus; cereal yellow dwarf virus; DAS-ELISA; CP gene; RT-PCR; PAV-II

\section{Introduction}

Barley yellow dwarf virus (BYDV) causes severe leaf symptoms in cereal crops. It is vectored by many aphids following a persistent and circulative manner (Oswald and Houston, 1951; Rochow and Muller, 1971; D'Arcy and Domier, 2005). It is a single-stranded RNA virus belonging to the Luteoviridae family. Currently, viruses that cause barley yellow dwarf disease either are assigned to Polerovirus or Luteovirus genera, or are unclassified. On the basis of their genome structure, some BYDV species have been renamed as Cereal yellow dwarf virus (two species, CYDV-RPV and CYDV-RPS) and included in the genus Polerovirus (D'Arcy, 1995; Van Regenmortel et al., 2000) while others (BYDV-

*Corresponding author: E-mail: Md.Makni@fst.rnu.tn; phone: +216-71-872-600.

Abbreviations: $\mathrm{BYDV}=$ barley yellow dwarf virus; $\mathrm{CP}=$ coat protein; CYDV = cereal yellow dwarf virus
SGV, BYDV-GPV, and BYDV-RMV) are not currently assigned to any genus (Miller and Rasochova, 1997). The Luteoviridae family includes species assigned to the Luteovirus genus, based on differences in vector specificity and in serology, including BYDV-PAV, BYDV-MAV, BYDV-PAS, and tentatively BYDV-GAV (Van Regenmortel et al., 2000; D'Arcy and Domier, 2005).

Recombination events occurring during evolution, often trigger high sequence divergence $(>10 \%)$ between and within isolates. In this context, BYDV-PAV isolates have been recently separated, based on antibody reaction and genomic content, into three distinct subspecies, BYDV- PAV-I (PAV), BYDV- PAV-II (PAS), and BYDV- PAV- III (PAV-CN) (Bisnieks et al., 2004; D'Arcy and Domier, 2005; Liu et al., 2007; Wu et al., 2011; Jarosova et al., 2012).

Among Luteoviruses, the amino acid regions of the coat protein $(\mathrm{CP})$ defining epitopes on the virion surface are highly conserved (Mayo and Miller, 1999), so detection and identification of B/CYDV are mainly based on DAS-ELISA 
test (D'Arcy et al., 1989; Rizzo and Gray, 1992; Mayo and Ziegler-Graff, 1996).

Nucleic acid-based detection by RT-PCR is more sensitive than DAS-ELISA and can distinguish between virus species even with a low viral titer in infected plants (Henson and French, 1993; French, 1995; Fabre et al., 2003; Mahua and Joseph, 2007). The universal Luteovirus primer set, $\mathrm{Lu} 1 / \mathrm{Lu}$ 4 , that spans most of CP gene, was successfully used for detection and characterization of six members of Luteoviridae family: BYDV-PAV, BYDV-MAV, BYDV-SGV, CYDV-RPV, PLRV, and BWYV (Robertson et al., 1991).

In Tunisia, BYDV was first detected during 1985/1986 farming season first through visual surveying, as BYDV-like symptoms recorded on cereals in the North of the country. Later, serological tests were developed and revealed the prevalence of BYDV-PAV (Makkouk et al., 1990, 2001; Najar et al., 2000).

In this study DAS-ELISA tests and RT-PCR of partial CP gene were applied to identify and determine B/CYDV virus species infecting barley in Tunisia. The genetic diversity of the virus was then analyzed in comparison with other $\mathrm{B} / \mathrm{CYDV}$ isolates occurring throughout the world.

\section{Materials and Methods}

Sample collection. 240 barley leaves were randomly collected during the high infestation periods (March/April) in 2010/2011 growing season. A sampling of 40 leaves per field, was performed following a North-South trend including Teboursouk $(36.27 \mathrm{~N}$, $9.14 \mathrm{E})$ and Oued Zarga (36.40N, 9.26E) provinces in the Northern area; Kairouan (35.67N, 10.09E) and Ain Djelloula (35.48N, 9.47E) provinces in the Central area; Gabes $(33.52 \mathrm{~N}, 10.70 \mathrm{E})$ and Kebili $(33.70 \mathrm{~N}, 8.96 \mathrm{E})$ provinces in the Southern area. All samples were crushed and stored at $-80^{\circ} \mathrm{C}$.

Detection of BYDV by DAS-ELISA. Samples were tested by DASELISA (Clark and Adams, 1977), with the Bioreba AG detection kit (Switzerland), using the three antibodies BYDV-B, BYDV-F, and BYDV-RPV corresponding to BYDV-PAV, BYDV-MAV, and CYDV-RPV respectively. Reactions were evaluated by measuring the absorbance at $405 \mathrm{~nm}$. A 3-fold absorbance of the healthy control was considered as positive threshold.

$R T-P C R$, cloning and sequencing. Total RNA was extracted from samples showing ELISA values $>0.18$ according to Chomczynski and Sacchi (1987). Reverse transcription of CP viral genome was performed by using the Supercript ${ }^{\circ} I I$ Reverse Transcriptase (Invitrogen) with the downstream primer Lu 4 (5'-GTCTACCTATTTGG-3') that can match bases 3455 to 3468,4084 to 4097 and 4207 to 4220 of BYDV-PAV, BWYV and PLRV, respectively as described by Robertson et al. (1991). PCRs were carried out with the downstream primer Lu 4 and the upstream primer Lu 1 (5'-CCAGTGGTTR TGGTC-3') corresponding to bases 2938 to 2952 of BYDV-PAV (Miller et al., 1988), 3564 to 3578 of BWYV (Veidt et al., 1988) and
3687 to 3701 of PLRV (Van der Wilk et al., 1989). In each PCR, 100 ng of cDNA, 1X PCR buffer, $2 \mathrm{mmol} / 1 \mathrm{MgCl}_{2}, 0.2 \mathrm{mmol} / \mathrm{l}$ of each dNTP, 10 pmol primers and 1.25U GoTaq polymerase (Promega) were used. The PCR conditions were set to $94^{\circ} \mathrm{C}$ for $5 \mathrm{~min}$ as initial denaturation temperature and then 40 cycles of $94^{\circ} \mathrm{C}$ for $1 \mathrm{~min}, 41^{\circ} \mathrm{C}$ for $1 \mathrm{~min}$, and $72^{\circ} \mathrm{C}$ for $2 \mathrm{~min}$, and final extension was done at $72^{\circ} \mathrm{C}$ for $7 \mathrm{~min}$. PCR-amplified fragments were purified using a DNA gel extraction kit Wizard SV gel and PCR clean-up system (Promega) and then cloned into the pGEM-T easy vector (Promega). Plasmid extraction from recombinant clones was performed using PureLink quick plasmid miniprep kit (Invitrogen) following manufacturer's protocol. Positive clones were sequenced on both strands by an automated ABI3130 sequencer (Applied Biosystems).

Sequence analysis. All sequences were examined using BLASTN program (basic local alignment search tool nucleotide-nucleotide, http:// www.ncbi.nlm.nih.gov/BLAST/) and compared with each other using network system (version 4.6.1.1) (http://www. fluxus-engineering.com). DNA sequences of the best-matching viral relatives were searched using BLASTN and sequences were subsequently downloaded and used for the phylogenetic analysis. Multiple alignments of nucleotide sequences were performed using Clustal W and phylogenetic tree was performed by the Neighbor joining method (Kimura2) with bootstrap option of 1000 replicates, using MEGA 5.1 (Tamura et al., 2011). Multiple alignments of amino acid sequences were performed using GENEDOC (version 2.7) and amino acid identities were analyzed using MEGA 5.1.

\section{Results}

Serological typing and geographical distribution of $B / C Y D V$

Results of DAS-ELISA showed that forty samples were positive for B/CYDV infection. Thirty out of the 40 infected samples contained BYDV-PAV serotype, 7 contained BYDVMAV serotype and 10 infected samples contained CYDVRPV (Table 1).

Moreover, 35 out of the 40 infected samples contained a single serotype (25 BYDV-PAV, 5 BYDV-MAV, and 5 CYDV-RPV), 3 contained two serotypes (BYDV-PAV/ CYDV-RPV) and two contained three serotypes (Table 1).

A higher incidence of B/CYDV was detected in Tunisian Southern provinces (50\%); while Central and Northern areas were characterized by lower incidence $(27.5 \%$ and $22.5 \%$ positive samples, respectively).

\section{Molecular characterization of $B / C Y D V$ isolates}

RT-PCR assays were performed to amplify the partial sequence of CP on 40 positive samples. PCR products with Lu 1/Lu 4 primers were, as predicted for BYDV-PAV, 531 
Table 1. BYDV isolates detected on barley with DAS-ELISA and RT-PCR assays

\begin{tabular}{|c|c|c|c|c|c|c|c|c|}
\hline \multirow{2}{*}{\multicolumn{3}{|c|}{ Samples }} & \multicolumn{3}{|c|}{ Positive ELISA samples } & \multirow[b]{2}{*}{ Positive RT samples } & \multirow[b]{2}{*}{ Viral sequence identity } & \multirow[b]{2}{*}{ Acc. No. } \\
\hline & & & $\begin{array}{c}\text { PAV } \\
(\mathrm{T}+0.21) \\
\end{array}$ & $\begin{array}{c}\text { MAV } \\
(\mathrm{T}+0.18)\end{array}$ & $\begin{array}{c}\text { RPV } \\
(\mathrm{T}+0.19) \\
\end{array}$ & & & \\
\hline \multirow{9}{*}{$\begin{array}{l}\text { I } \\
\text { 荘 } \\
\text { Z }\end{array}$} & 光 & 1 & + & & & + & PAV-TN1 & JX402453 \\
\hline & $\stackrel{0}{\mathscr{D}}$ & 2 & + & & & + & PAV-TN1 & JX402453 \\
\hline & $\overline{0}$ & 3 & + & & + & + & PAV-TN2 & JX402454 \\
\hline & 局 & 4 & + & + & + & + & PAV-TN2 & JX402454 \\
\hline & & 5 & + & & & + & PAV-TN1 & JX402453 \\
\hline & 赵 & 6 & + & & & + & PAV-TN1 & JX402453 \\
\hline & N & 7 & + & & + & + & PAV-TN2 & JX402454 \\
\hline & $\stackrel{\mathscr{\Xi}}{3}$ & 8 & + & + & + & + & PAV-TN2 & JX402454 \\
\hline & & 9 & & + & & - & & \\
\hline \multirow{11}{*}{ 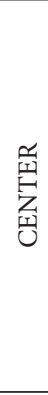 } & & 10 & + & & & + & PAV-TN1 & JX402453 \\
\hline & ซี & 11 & + & & & + & PAV-TN1 & JX402453 \\
\hline & $\tilde{D}$ & 12 & + & & & + & PAV-TN1 & JX402453 \\
\hline & 氙 & 13 & + & & & + & PAV-TN6 & KF271792 \\
\hline & & 14 & & & + & - & & \\
\hline & & 15 & + & & & + & PAV-TN1 & JX402453 \\
\hline & $\frac{\pi}{3}$ & 16 & + & & & + & PAV-TN1 & JX402453 \\
\hline & 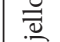 & 17 & + & & & + & PAV-TN1 & JX402453 \\
\hline & $\ddot{\theta}$ & 18 & & + & & - & & \\
\hline & & 19 & & & + & - & & \\
\hline & & 20 & + & & + & + & PAV-TN6 & KF271792 \\
\hline \multirow{20}{*}{$\begin{array}{l}\mathbb{I} \\
\text { 岁 } \\
\text { O }\end{array}$} & & 21 & + & & & + & PAV-TN3 & JX402455 \\
\hline & & 22 & + & & & + & PAV-TN3 & JX402455 \\
\hline & & 23 & + & & & + & PAV-TN3 & JX402455 \\
\hline & & 24 & + & & & + & PAV-TN3 & JX402455 \\
\hline & & 25 & + & & & + & PAV-TN5 & JX402457 \\
\hline & & 26 & + & & & + & PAV-TN5 & JX402457 \\
\hline & & 27 & + & & & + & PAV-TN5 & JX402457 \\
\hline & $\mathscr{8}$ & 28 & + & & & + & PAV-TN5 & JX402457 \\
\hline & $\overline{0}$ & 29 & + & & & + & PAV-TN5 & JX402457 \\
\hline & & 30 & + & & & + & PAV-TN5 & JX402457 \\
\hline & & 31 & + & & & - & & \\
\hline & & 32 & & + & & - & & \\
\hline & & 33 & & + & & - & & \\
\hline & & 34 & & & + & - & & \\
\hline & & 35 & & & + & - & & \\
\hline & & 36 & & & + & - & & \\
\hline & & 37 & + & & & + & PAV-TN4 & JX402456 \\
\hline & $\overline{0}$ & 38 & + & & & + & PAV-TN4 & JX402456 \\
\hline & 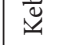 & 39 & + & & & + & PAV-TN4 & JX402456 \\
\hline & & 40 & & + & & - & & \\
\hline
\end{tabular}

bp long in 29 samples infected by BYDV-PAV. Samples with a single infection by BYDV-MAV and/or CYDV-RPV serotypes failed amplification. All 29 PCR products were cloned and three random clones were sequenced from each RT-PCR product. BLASTN of the non-redundant database revealed six BYDV-PAV haplotypes which were named PAV-TN1 to PAV-TN6 and registered in GenBank Acc. No. JX402453 to JX402457 and KF271792 (Table 1). Analysis of sequences from each sample didn't detect multiple infections. Analysis of frequency distributions showed a predominance of PAVTN1 with $34.5 \%$ (10 out of 29 ) in the Northern and Central regions. The PAV-TN2 haplotype was detected only in the North with a frequency of $13.8 \%$ (4 out of 29). Likewise, PAV-TN6 was specific to the Center with an incidence of $6.9 \%$ (2 out of 29). In the Southern area, three haplotypes were identified as follows: PAV-TN3 13.8\% (4 out of 29), PAV-TN4 10.3\% (3 out of 29) and PAV-TN5 20.7\% (6 out of 29) (Table 1).

Tunisian BYDV sequences and frequencies were incorporated to Median Joining Network to depict haplotypes relationships (Fig. 1). Sequence similarity network showed that the main haplotype PAV-TN1 was directly linked to 
the five remaining Tunisian haplotypes. Indeed, PAV-TN6 was the closest to PAV-TN1 differing by only one nucleotide substitution. However, sequences of the three haplotypes PAV-TN4, PAV-TN3, and PAV-TN5 differed from PAV-TN1 by 12,14 , and 23 nucleotides, respectively. The PAV-TN2 haplotype was the most divergent and was distinct by 38 nucleotides from PAV-TN1.

\section{Phylogenetic analysis}

The CP partial nucleotide sequences of the six Tunisian BYDV-PAV haplotypes were compared with 19 haplotypes from the family Luteoviridae available in GenBank.

In the phylogenetic tree, all haplotypes of BYDV-PAV (PAV-I, PAV-II, PAV-III), including those from Tunisia and BYDV-MAV formed a unique well supported group (genus Luteovirus) whereas haplotypes of CYDV-RPV and PLRV formed a different group (genus Polerovirus) with high bootstrap support (Fig. 2). Four well-supported clusters were observed within the genus Luteovirus: BYDV-PAV-I, BYDV-PAV-II, BYDV-PAV-III, and BYDV-MAV.

PAV-TN1 and PAV-TN6 haplotypes belonged to a very tight cluster (>98\%) corresponding to BYDV subspecies PAV-II comprising isolates from Morocco, Czech Republic, France and Germany. The remaining haplotypes PAV-TN2, PAV-TN3, PAV-TN4, and PAV-TN5 were clustered in another group. Based on analysis of CP sequences, geographical origin of BYDV-PAV-II seems to be an important factor influencing genetic diversity of this virus.

\section{Amino acid analysis}

Amino acid sequences of Tunisian haplotypes were aligned with known sequences of BYDV-PAV and BYDVMAV (Fig. 3). The alignment revealed that the coat protein had a conserved amino acid motif "PDSIPGS", at position 50-56 which is usually present in BYDV-PAV-II-like viruses including PAV-II Mo9517, PAV-II Czech Republic, PAV-II FH1, PAV-II G, PAV-II-Io, PAV-II Alaska, PAV-II New Zealand, PAV-II Pakistan, PAV-II USA, and PAV-II California. Otherwise, Tunisian sequences showed one amino acid substitution (D51E) for PAV-TN2 and PAVTN4 in the motif PDSIPGS. Sequence identities were calculated and are reported in Table 2. The two amino acid sequences of PAV-TN1 and PAV-TN6 haplotypes from Tunisia showed the highest identity (100\%) with BYDVPAV-II haplotype from Morocco and from Czech Republic, followed by $99.3 \%$ with BYDV-PAV-II haplotype from France and Germany with a single substitution F170L and A45E, respectively.

Moreover, PAV-TN2 sequence did not show amino acid identity higher than $87.3 \%$ to any other previously characterized BYDV-PAV-II haplotypes.

\section{Discussion}

At both, genomic and pathogenicity levels, great divergence was reported in BYDV-PAV from several countries (Wu et al., 2011). To date, the genetic structure of BYDVPAV natural populations has never been explored in Tunisia, despite its economical importance and high diversity.

Earlier studies on Tunisian B/CYDV, based on serological assays against coat protein of five BYDV strains (PAV, MAV, RPV, RMV, and SGV) showed that BYDV-PAV serotypes were the most prevalent followed by BYDV-MAV and CYDV-RPV ones (Makkouk et al., 1990; Najar et al., 2000; Makkouk et al., 2001). In our study, the diversity of BYDV-PAV was investigated based on CP gene from 240 barley samples collected in six fields. DAS-ELISA confirmed the presence of BYDV in 40 samples out of 240 with a high prevalence of BYDV-PAV serotype in 30 out of 40 positive samples (75\%), followed by the CYDV-RPV and BYDVMAV serotypes with $25 \%$ and $17.5 \%$, respectively.

Comparison between regions showed a remarkable difference in BYDV incidence. The Southern provinces showed a higher incidence than the Central and Northern areas. This variation could be attributed to a number of factors including differences between the south and the rest of the country in terms of sowing dates, field surfaces, weather conditions and availability of alternate hosts fields (Miller et al., 1988; Robert and Lemaire, 1999, Smyrnioudis et al., 2001; Hall, 2007).

During the last few years, identification and comparison of viruses have become precise and unique with implementation of molecular methods, since many different haplotypes of B/CYDV were described.

In our study, the universal Lu $1 / \mathrm{Lu} 4$ primers, widely used for sensitive detection of most members of the Luteoviridae family (Robertson et al., 1991; Robertson and French, 2007), were used to amplify the CP gene of B/CYDV positive samples. Results showed that 29 out of 40 samples were positive in RT-PCR. Samples displaying BYDV-MAV and /or -RPV infections failed to amplify CP gene even after several attempts by RT-PCR indicating that these samples were false positive in DAS-ELISA. Each RTPCR product was cloned and sequenced. BLASTN showed that all sequences belonged to six different BYDV-PAV haplotypes, and multiple infections were not detected at nucleotide sequence level.

Moreover, the relationships network strongly suggests that at least one mutation event, involving the PAV-TN1, have contributed to the evolutionary history of these haplotypes.

Phylogenetic analysis showed that samples sequenced in this study were grouped with BYDV-PAV-II subspecies and that the two Tunisian isolates PAV-TN1 and PAV-TN6 were most closely related to haplotypes from Morocco, Czech Republic, France and Germany. The occurrence of 


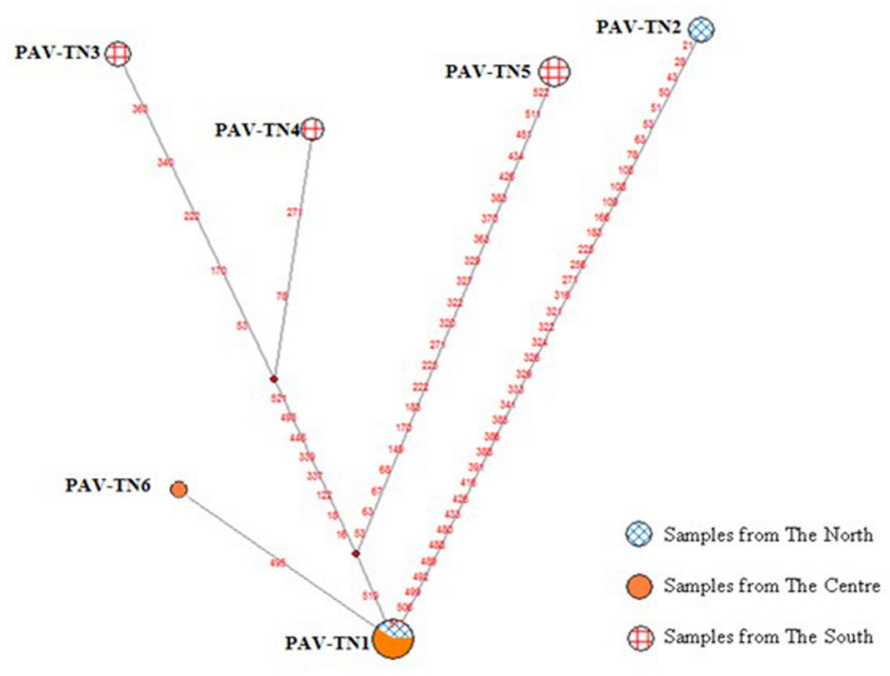

Fig. 1

Median joining network indicating the differences between isolates

The size of each circle reflects the frequency of the corresponding isolate. Geographical locations are depicted in different forms.

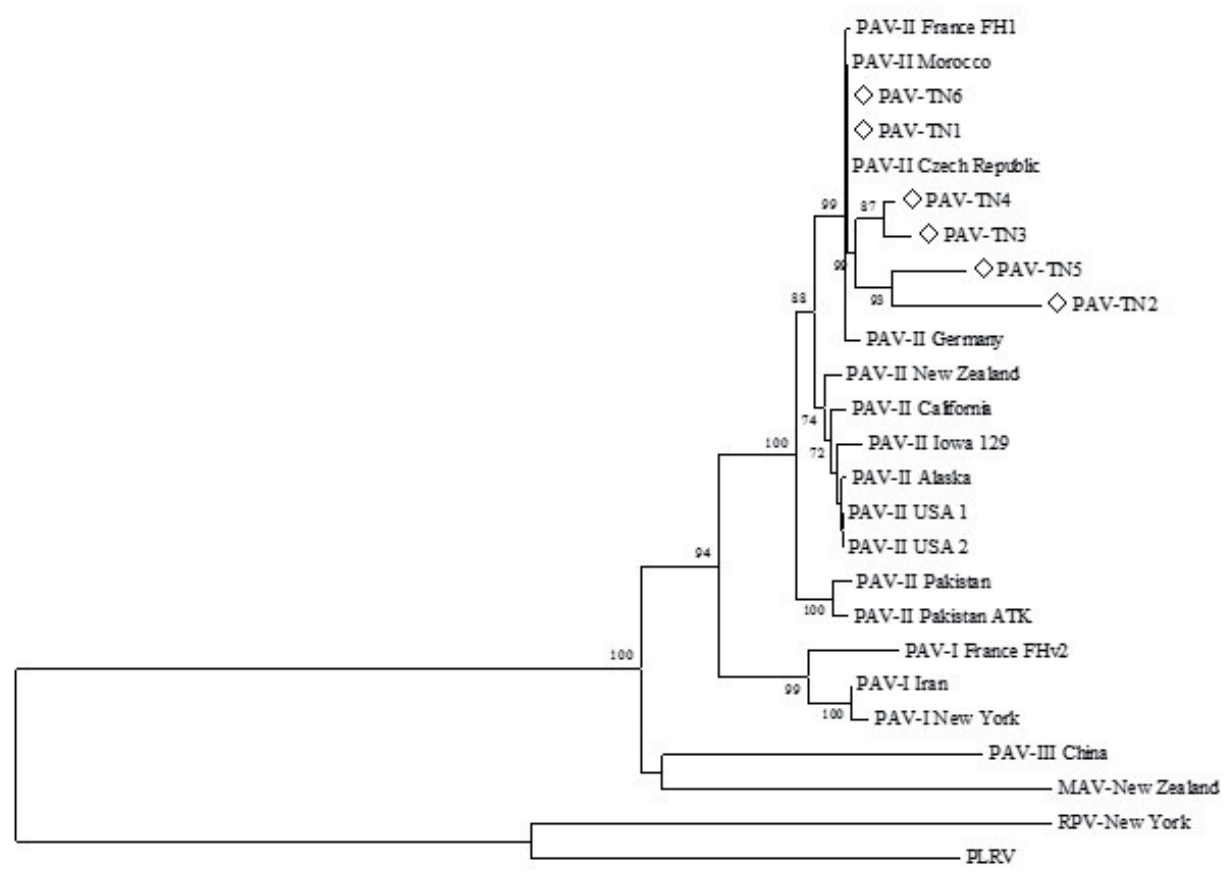

Fig. 2

Phylogenetic tree of BYDV isolates based on 531 nucleotide sequences of partial CP region

Tree was constructed by the Neighbor-Joining method and the statistical significance of branches was evaluated by bootstrap analysis. Only bootstrap values above $70 \%$ are indicated. The scale bar represents a distance of 0.05 substitutions per site. The Acc. Nos of used BYDV sequences are: AY450454 (PAV-I-IR: Iran), AJ007492.1 (PAV-I-FHv2: France), X56050.1 (PAV-I-NY: New York), AJ223588.1 (PAV-II-FH1: France), AF218798 (PAV-II-129: Iowa), AJ810418(PAV-II-G: Germany), AJ007927 (PAV-II-MA9517: Morocco), DQ683252 (PAV-II Alaska), EF408155 (PAV-II New Zealand), DQ631855 (PAV-II California), DQ285677 (PAV-II USA1), DQ285676 (PAV-II USA2), GU247983 (PAV-II Pakistan), GU247978 (PAV-II Pakistan ATK), FJ645763 (PAVII-CR: Czech Republic), EU332331.1 (PAV-III-Ch: China), GU002360.1 (MAV-NZ: New Zealand). Potato leaf roll virus (PLRV) AF453391 and cereal yellow dwarf virus species (CYDV- RPV-New York) D10206 were used as out-groups. 

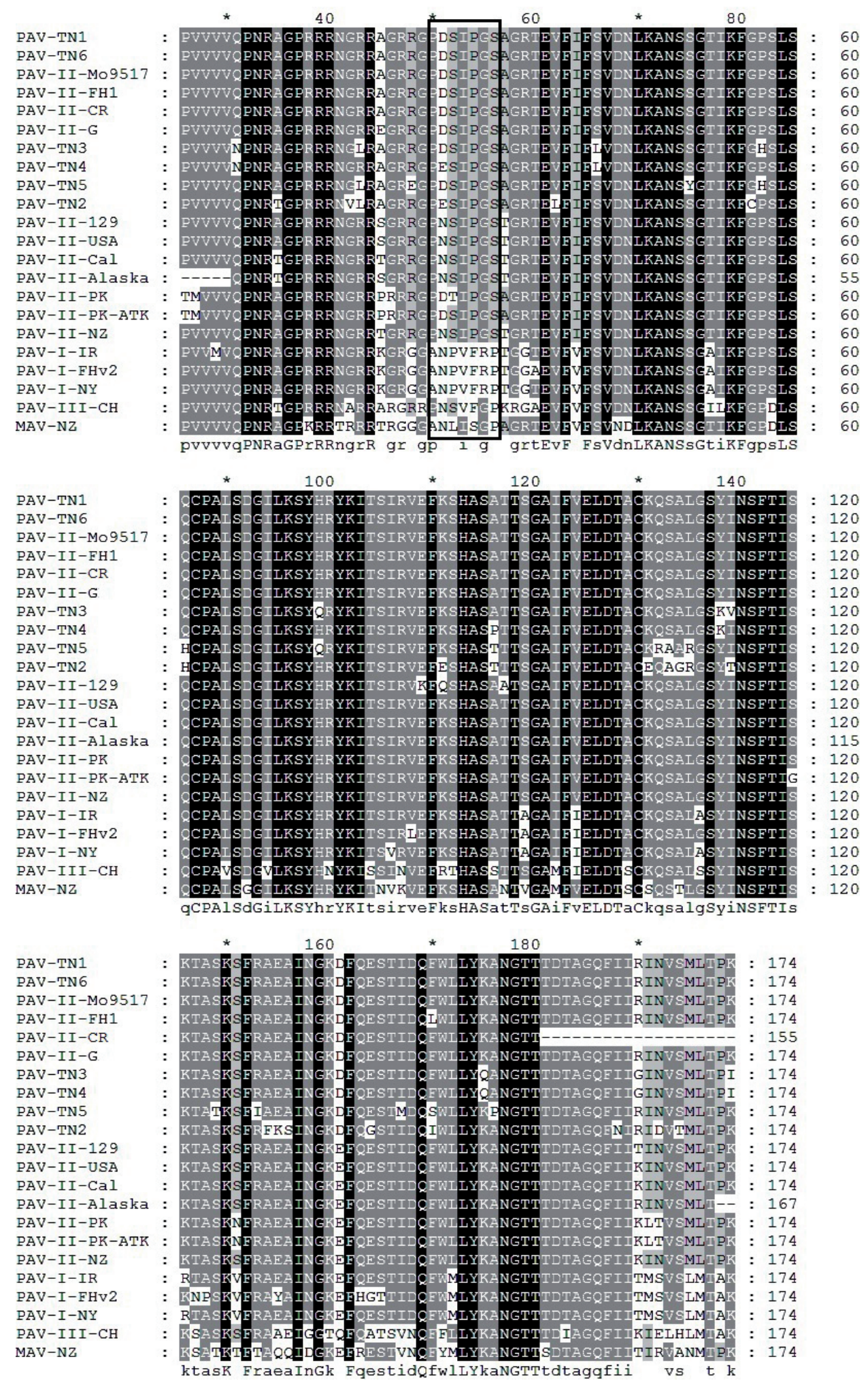

Fig. 3

Alignment of amino acid sequences of the coat protein region of BYDV isolates from Czech Republic, France, Germany, Iran, Morocco, New Zealand, Pakistan, Tunisia, and USA (Alaska, California, Iowa, New York)

Framed area corresponds to the conserved specific motif PDSIPGS of subspecies PAV II. 


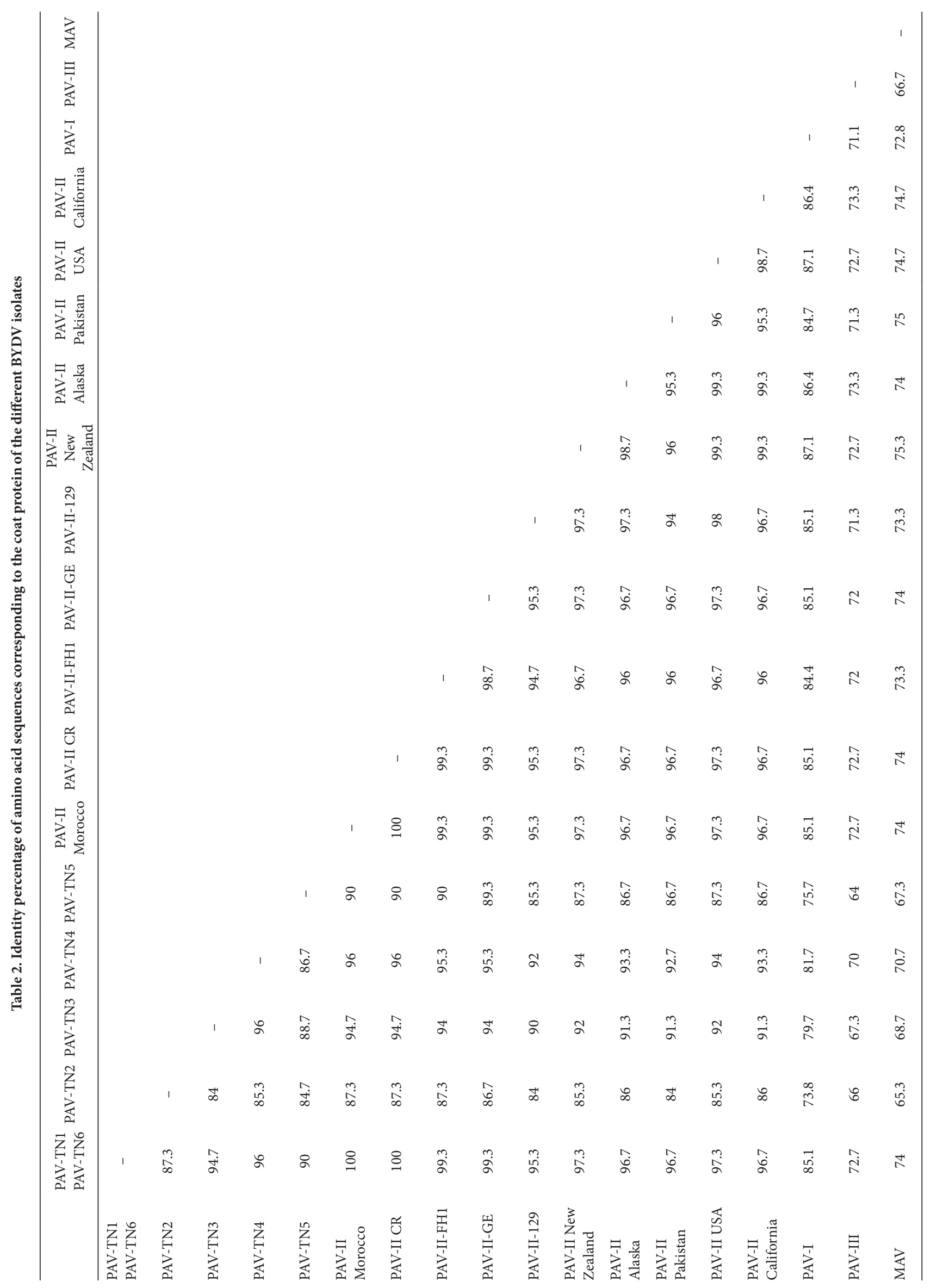


these haplotypes in different countries could be explained by migration of aphids having the same origin.

Results of CP amino acid sequence analysis showed the presence of the conserved amino acid motif "PDSIPGS" that is usually present in BYDV-PAV-II isolates (Liu et al., 2007; Kundu et al., 2009).

Since PAV-TN2 and PAV-TN5 exhibit a difference at amino acid level exceeding 10\%, a threshold used to distinguish species within the Luteoviridae family (Bisnieks et al., 2004; Liu et al., 2007; Wu et al., 2011; Jarosova et al., 2012), our results showed that PAV-TN2 and PAV-TN5 haplotypes represent a well separated cluster inside of PAV-II cluster and therefore couldn't be considered as new subspecies.

This study represents the first report of BYDV-PAV-II haplotypes in Tunisia and revealed a differential distribution of those B/CYDV haplotypes according to regions. Our reports will be very useful to implement efficient control measures against B/CYDV disease in Tunisia.

Acknowledgements. This work was funded by PRF project between the Ministry of Higher Education and Scientific Research (Tunisia) and the Ministry of Agriculture (Tunisia).

\section{References}

Bisnieks M, Kvarnheden A, Sigvald R, Valkonen JPT (2004): Molecular diversity of the coat protein-encoding region of Barley yellow dwarf virus-PAV and Barley yellow dwarf virus-MAV from Latvia and Sweden. Arch. Virol. 149, 843-853. http://dx.doi.org/10.1007/s00705-003-0242-2

Chomczynski P, Sacchi N (1987): Single-step method of RNA isolation by acid guanidinium thiocyanate-phenol-chloroform extraction. Anal. Biochem. 162, 156-159. http://dx.doi. org/10.1016/0003-2697(87)90021-2

Clark MF, Adams AN (1977): Characteristics of the microplate method of enzyme linked immunosorbent assay for the detection of plant viruses. J. Gen. Virol. 34, 475-483. http://dx.doi.org/10.1099/0022-1317-34-3-475

D'Arcy CJ, Torrance L, Martin RR (1989): Discrimination among luteoviruses and their strains by monoclonal antibodies and identification of common epitopes. Phytopathology 79, 869-873. http://dx.doi.org/10.1094/Phyto-79-869

D'Arcy CJ (1995): Symptomology and host range of barley yellow dwarf. In D'Arcy CJ, Burnett PA (Eds): Barley Yellow Dwarf: 40 Years of Progress. St Paul,MN, USA: APS Press, pp. 9-28.

D'Arcy CJ, Domier LL (2005) Family Luteoviridae. In Fauquet CM, Mayo MA, Maniloff J, Desselberger U, Ball LA (Eds): Virus Taxonomy. VIIIth Report of International Committee on Taxonomy of Viruses. London: Elsevier/ Academic Press, pp. 891-900.

Fabre F, Kervarrec C, Mieuzet L, Vialatte A, Jacquot E (2003): Improvement of Barley yellow dwarf virus-PAV detection in single aphid using real-time RT-PCR fluorescent method.
J. Virol. Methods 110, 51-60. http://dx.doi.org/10.1016/ S0166-0934(03)00097-1

French R (1995): Barley yellow dwarf: diagnostic procedures and reagents. In Burnett PA (Ed.): Barley Yellow Dwarf: 40 Years of Progress. American Phytopathological Society, St. Paul, MN, pp. 293-305.

Hall GS (2007): The effect of within-host virus population growth and interspecific competition on aphid transmission and population structure of Barley yellow dwarf virus: Cornell University, $\mathrm{PhD}$ thesis.

Henson J, French R (1993): The polymerase chain reaction and plant disease diagnosis. Annu. Rev. Phytopathol. 143, 369-373.

Jarosova J, Chrpova J, Sip V, Kundu JK (2012): A comparative study of the Barley yellow dwarf virus species PAV and PAS: distribution, accumulation and host resistance. Plant. Pathol. 62, 436-443. http://dx.doi.org/10.1111/j.13653059.2012.02644.x

Kundu JK, Jarosova J, Gadiou S, Cervena G (2009): Discrimination of three BYDV species by one-step RT-PCR-RFLP and sequence based methods in cereal plants from the Czech Republic. Cereal Res. Commun. 37, 541-550. http:// dx.doi.org/10.1556/CRC.37.2009.4.7

Liu F, Wang X, Liu Y, Xie J, Gray SM, Zhou G, Gao B (2007): A Chinese isolate of Barley yellow dwarf virus-PAV represents a third distinct species within the PAV serotype. Arch. Virol. 152, 1365-1373. http://dx.doi.org/10.1007/ s00705-007-0947-8

Mahua D, Joseph MA (2007): Development of a multiplexed PCR detection method for Barley and Cereal yellow dwarf viruses, Wheat spindle streak virus, Wheat streak mosaic virus and Soil-borne wheat mosaic virus. J. Virol. Methods 148, 7-24.

Makkouk KM, Azzam OI, Skaf J, El-Yamani M, Cherif C, Zouba A (1990): Situation review of Barley yellow dwarf virus in West Asia and North Africa. In Burnett PA (Ed.): World Perspectives on Barley Yellow Dwarf. CIMMYT, Mexico, D.F., Mexico, pp. 61-65.

Makkouk KM, Najar A, Kumari S (2001): First record of Barley yellow dwarf and Cereal yellow dwarf viruses in Tunisia. Plant. Pathol. 50, 806. http://dx.doi.org/10.1046/j.13653059.2001.00629.x

Mayo MA, Ziegler-Graff V (1996): Molecular biology of luteoviruses. Adv. Virus. Res. 46, 413-460. http://dx.doi. org/10.1016/S0065-3527(08)60077-9

Mayo MA, Miller WA (1999): The structure and expression of luteovirus genomes. In Smith HG, Barker H (Eds): The Luteoviridae. Wallingford, UK: CABI Publishing, pp. 23-42.

Miller WA, Waterhouse PM, Gerlach WL (1988): Sequence and organization of barley yellow dwarf virus genomic RNA. Nucleic. Acids. Res.16, 6097-6112. http://dx.doi. org/10.1093/nar/16.13.6097

Miller WA, Rasochova L (1997): Barley yellow dwarf viruses. Annu. Rev. Phytopathol. 35, 167-190. http://dx.doi.org/10.1146/ annurev.phyto.35.1.167

Najar A, Makkouk KM, Boudhir H, Kumari S, Bessai R, Ben Othman F (2000): Viral diseases of cultivated legume 
and cereal crops in Tunisia. Phytopathol. Mediterr. 39, 423-432.

Oswald JW, Houston BR (1951): A new virus disease of cereals transmissible by aphids. Plant. Dis. 15, 471-475.

Rizzo TM, Gray SM (1992): Localization of a surface domain of the capsid protein of Barley yellow dwarf virus. Virology 186, 300-302. http://dx.doi.org/10.1016/0042-6822(92) $90085-4$

Robert Y, Lemaire O (1999): Introduction to Luteovirus epidemiology. In Smith HG, Barker H (Eds): The Luteoviridae. Oxon, CAB International, pp. 213-220.

Robertson NL, French R, Gray SM (1991): Use of group-specific primers and the polymerase chain reaction for the detection and identification of luteoviruses. J. Gen. Virol. 72, 1473-1477. http://dx.doi.org/10.1099/0022-131772-6-1473

Robertson NL, French R (2007): Genetic analysis of a novel Alaska Barley yellow dwarf virus in the family Luteoviridae. Arch. Virol. 152, 369-382. http://dx.doi.org/10.1007/ s00705-006-0846-4

Rochow WF, Muller I (1971): A fifth variant of Barley yellow dwarf virus in New York. Plant. Dis. 55, 874-877.

Smyrnioudis IN, Harrington R, Clark SJ, Katis N (2001): The effect of natural enemies on the spread of Barley yellow dwarf virus (BYDV) by Rhopalosiphum padi (Hemiptera:
Aphididae). Bull. Entomol. Res. 91, 301-306. http:// dx.doi.org/10.1079/BER2001110

Tamura K, Peterson D, Peterson N, Stecher G, Nei M, Kumar S (2011): MEGA5: Molecular evolutionary genetics analysis using maximum likelihood, evolutionary distance, and maximum parsimony methods. Mol. Biol. Evol. 28, 2731-2739. http://dx.doi.org/10.1093/molbev/msr121

Van Der Wilk F, Huisman MJ, Cornelissen BJ, Huttinga H, Goldbach $R$ (1989): Nucleotide sequence and organization of Potato leafroll virus genomic RNA. FEBS Letters 245, 51-56. http://dx.doi.org/10.1016/0014-5793(89)80190-5

Van Regenmortel MH, Mayo MA, Fauquet CM, Maniloff J (2000): Virus nomenclature: consensus versus chaos. Arch. Virol. 145, 2227-2232. http://dx.doi.org/10.1007/ $\underline{\text { s007050070053 }}$

Veidt I, Lot H, Leiser RM, Scheidecker D, Guilley H, Richards K, Jonard G (1988): Nucleotide sequence of beet western yellows virus RNA. Nucleic. Acids. Res.16, 9917-9932. http://dx.doi.org/10.1093/nar/16.21.9917

Wu B, Blanchard-Letort A, Liu Y, Zhou G, Wang X, Elena SF (2011): Dynamics of molecular evolution and phylogeography of Barley yellow dwarf virus-PAV. PLoS One 6: e16896. DOI:10.1371/journal.pone.0016896. http://dx.doi. org/10.1371/journal.pone.0016896 